\title{
奥行き移動する視標に対する輻輳と調節応答の解析
}

\section{Dependence on the Display Methods for Changes in Accommodation and Convergence When a Target Moves along the Depth Direction}

\author{
横 山 優 樹†, \\ 高比良 英朗 ${ }^{\dagger}$, \\ 望月信 哉 ${ }^{\dagger}$, 正会員 山田光 穗
}

Yuki Yokoyama $^{\dagger}$, Hideaki Takahira ${ }^{\dagger}$, Shinya Mochiduki ${ }^{\dagger}$ and Mitsuho Yamada ${ }^{\dagger}$

\begin{abstract}
あらまし われわれは電子端末の使いやすさ, 見やすさについて, 目のピント調節と輻輳眼球運動の追従精度から評価できないか 検討を行っている．視標を奥行き方向にリニアに移動させることができる装置と組合せ，眼球の水晶体調節と輻輳眼球運動を同時に 測定する実験装置を開発し，表示媒体，フォントサイズ，文字フォントといったパラメータを変化させ，奥行き方向に移動させた際の 輻輳眼球運動と調節応答の分析を行った。その結果，調節変化量は奥行き移動量に近いものの，表示媒体，フォントサイズ，文字フォ ントによって違いがあること，輻輳の変化量は，これらのパラメータに依存する傾向はあまりみられなかった。
\end{abstract}

キーワード : 眼球運動, 調節, 輻輳, 電子書籍

\section{1. まえ がき}

近年の電子端末の普及からスマートフォンやタブレット 端末といった小型で軽量の電子端末を持ち歩き，バスや電 車等の摇れる移動体内で利用することが常態化している. このような移動体内で電子端末を利用する際には，電子端 末を一定の距離で保持し続けることは難しく，摇れや振動 の影響により利用者と電子端末の視距離が変化することが 考えられる。特に，電子書籍のように文字を読む際には読 み手と電子端末との距離によりその可読性や読みやすさが 変化することが予想され, 電子端末との距離による影響を 検証する必要性があると考えた。

そこで，まず可読性や読みやすさの評価について，これ までの研究を振り返る。この分野の研究では, 端末との距 離を考慮したものよりも媒体の表示形式に着目した研究が 多く行われている．紙書籍の可読性については，大正時代 から行われており, 大きさと書体, 縦組みと横組み, 字詰め と字間，印刷インキと紙質などをパラメータとして，読了 時間, 眼球運動の停留数, 眼球運動の逆行数の少なさから 評価が行われている1)。ロービジョンや加齢者の読みやす さを考慮したユニバーサルフォントに対して可読性が評価 されている ${ }^{2) 3)}$. 紙媒体から電子媒体への移行が顕著になっ た 2000 年前後から, 主に LCD を対象とした研究が増加し ている。たとえば，表示輝度，コントラスト，文字サイズ を変化させた高齢者の視覚特性に適合した液晶ディスプレ イの表示条件 ${ }^{4)}$, 読み取り速度の影響5)について検討が行わ

2015年3月 19 日受付，2015年 7 月 27 日再受付，2015年 9 月 14 日採録 †東海大学 情報通信学研究科

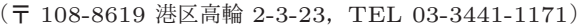

れ，高齢者では低輝度ではコントラスト感が低くなること， フォントの線幅を太くする必要があることが報告されてい る。そのほか可読性に関しては，LCD を用いて，画素密度 とフォントを変化させて実験を行い, 低画素密度でフォン トが小さいと読書速度が低下し，フォントと読書速度に相 関があることが示されている ${ }^{6)}$. 可読性に比べて文書理解 の研究は少ないが，フォントサイズを変化させて理解度を 測定した結果，印刷物，LCD， CRT の順になること，特 にフォントサイズが小さい場合には，印刷物による理解度 が有意に高く，ゴシック体と明朝体では，ゴシック体の方 が有意に高いことが報告されている7 ，以上に述べたよう に, 紙書籍, LCD 表示に対する可読性や理解度の研究につ いては多くみられるが，その要因を生理的に探った研究は あまりない，また，表示媒体を利用する場面を想定して媒 体を移動させ視距離を変化させて評価した研究もない.

そこで，本研究では奥行き方向に摇れる電子端末の可読 性や読みやすさを客観的に評価することを目的として，眼 の重要な機能である眼球運動と水晶体の調節に着目し, 物 体を見る際の奥行き知覚の手がかりとなる輻輳眼球運動と 調節の応答の測定を行った。自由に読書しているときの調 節応答を取得するのは現状の技術では困難であるため，そ の基礎的な検討として，フォントとフォントサイズをパラ メータに複数の表示端末を用い，奥行き方向に移動する文 字を注視時の輻輳眼球運動と調節応答を測定した。本研究 の前に予備実験として，視標に文字「東」を提示し，表示 媒体を奥行き方向に移動させた際の輻輳眼球運動と調節応 答を測定した。そして，明朝体とゴシック体といったフォ ントによる比較を，フォントサイズの違いも加えて行った。 その結果，フォントの違いによって調節の応答に影響があ 
る可能性が示唆された ${ }^{8)}$. 本稿では, 予備実験を踏まえて実 験条件を整理し, 視標をより汎用性があり明朝体・ゴシック 体と似た特徴の欧文フォントの文字に変更し, 実験を行っ た結果を報告する。

\section{2. 調 節 · 輻 輳}

\section{1 焦点調節機能}

物を注視する際，水晶体の厚さを変化させることで屈折 力を調節し, 対象物へ焦点を合わせる機能を水晶体調節機能 という.（図 1）水晶体は毛㥞体筋に支えられており，近方 視の場合はこの毛様体筋が収縮し, 水晶体が厚くなる. 遠 方視の場合は毛様体筋が弛緩し, 水晶体が薄くなる．水晶 体の屈折力 (調節力) の単位として, ディオプター (diopter, D）がある. ディオプターは視距離の逆数をとり, $\mathrm{D}=1 / \mathrm{m}$ で算出される. $1 \mathrm{D}$ は $1 \mathrm{~m}$ 先の眼前にある物を見るときの 必要な調節力にあたる.

\section{2 輻輳眼球運動}

人には対象物を左右の両目で見る両眼視機能がある。（図 2) 両眼視で近くの対象物を見るとき, 両目を内側に寄せ, 注視しようとする働きを輻輳運動という. 対して, 遠くの 対象物を見る際, 両目を外側に開き, 認識しようとする働 きを開散運動という。この輻輳開散運動で対象物をとらえ ることにより，奥行きを知覚している.

\section{3. 実験装置の構成}

実験装置の構成図を図 3 に示す，調節の測定にはシギヤ 精機 (株) WAM-5500 を用いた. WAM-5500 は約 $7 \mathrm{~Hz}$ の 連続測定が可能である。この WAM-5500 について, Shepperd and Davis は, -6.38 から $+4.88 \mathrm{D}$ の範囲であれば, $-0.01 D \pm 0.38 D$ の精度で測定可能であることを示してい る ${ }^{9)}$. また, 輻輳眼球運動の測定には, ナックイメージテ クノロジー, アイマークレコーダー EMR-9 を用いた。測 定間隔は $60 \mathrm{~Hz}$ である。WAM-5500 は 950nm, EMR-9 は $850 \mathrm{~nm}$ の近赤外光を測定に使用し，お互いに干渉しないた め, 良好に眼球運動と焦点調節が同時測定できることを塩 見らは示している10).

本実験のために, レール制御と同時に調節と眼球運動の 同時測定を行うプログラムを開発した。このプログラムで は, WAM-5500 に測定開始要求を送ると測定を開始し, 同 時に, アイマークレコーダーからの出力データを記録し始 める。レール制御装置に駆動命令を送ると被験者に視標の 移動開始を予測されないようにランダムに $1 \sim 3$ 秒待機した 後レールが駆動する.この時, レールが動き出したタイミ ングが出力データから読み取れるように, 駆動開始キュー がデータに出力される.

\section{4. 実 験 方 法}

被験者には実験中, 視標を注視し続けるように指示した。 視標は視距離 $60 \mathrm{~cm} \rightarrow 40 \mathrm{~cm}, 40 \mathrm{~cm} \rightarrow 60 \mathrm{~cm}$ の順番で移

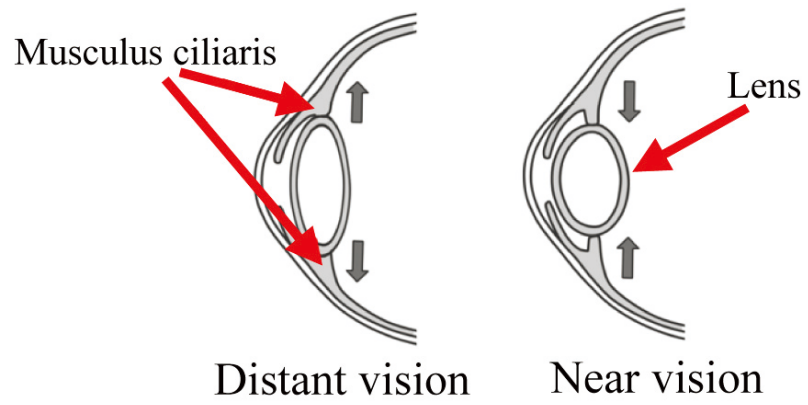

図 1 焦点調節機能

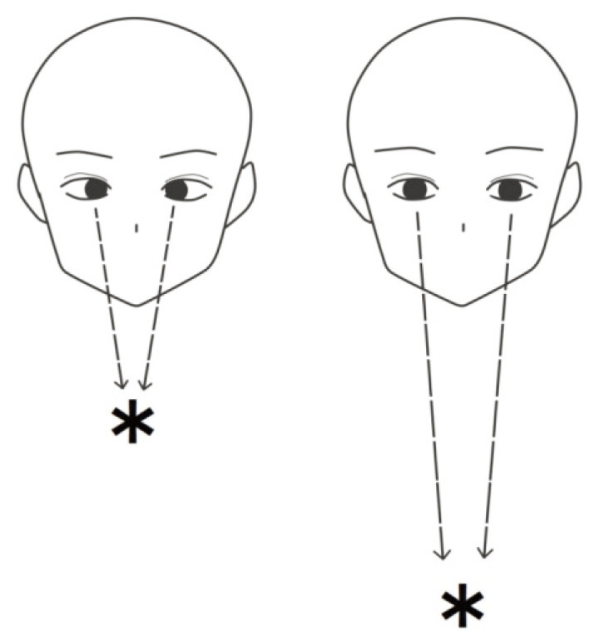

図 2 輻輳開散運動

動するのを 1 セットとし，各パラメータで 2 セットずつ測 定を行った。被験者に視標の移動開始を予測されないよう に, 各移動の間の静止時間は, $5 \sim 7$ 秒の間でランダムに変 化させた。レールの移動速度は約 $12 \mathrm{~mm} / \mathrm{sec}$ である．視距 離 $60 \mathrm{~cm}$ の位置で EMR-9 のキャリブレーションを行い, その後, 同じ位置でオフセットを行った。

表示媒体には再生紙, 電子ペーパー (KOBO mini，5 个 ンチ), LCD(iPod, 4 インチ), 有機 $\mathrm{EL}(\mathrm{PS}$ Vita，5 イン チ)を使用した。表 1 に紙を除く各デバイスの画素ピッチ, 紙と反射型の KOBO mini については垂直面照度, 発光型 の iPod, PS Vita については白ピークと黒背景での輝度 值，コントラストを示す．発光型ではないが，紙と反射型 の KOBO mini についても白ピークと黒背景での輝度值, コントラストを参考值として示した。また，実験条件で 4 つの媒体を撮影した写真を図 4 に示す。紙と $\mathrm{KOBO}$ mini では後者の輝度值，コントラストが低く，そのことは図 4 からもわかるが, 実験者側であらかじめ読みやすいコント ラストに調整しており, 視認性の問題はないと考えている. 有機 EL の PS Vitaについては, 元々ゲーム端末であり, 細 かな調整は困難であったができる限り, iPodに近づけた。 iPod と PS Vita では色温度が異なり, 図 4 の写真では輝度 差が感じられるが, 実際に目で見た比較では, KOBO mini 以外は，ほぼ同じ明るさであった。なお，反射型の KOBO mini では光源からのグレアの影響を受けると見にくくなる 


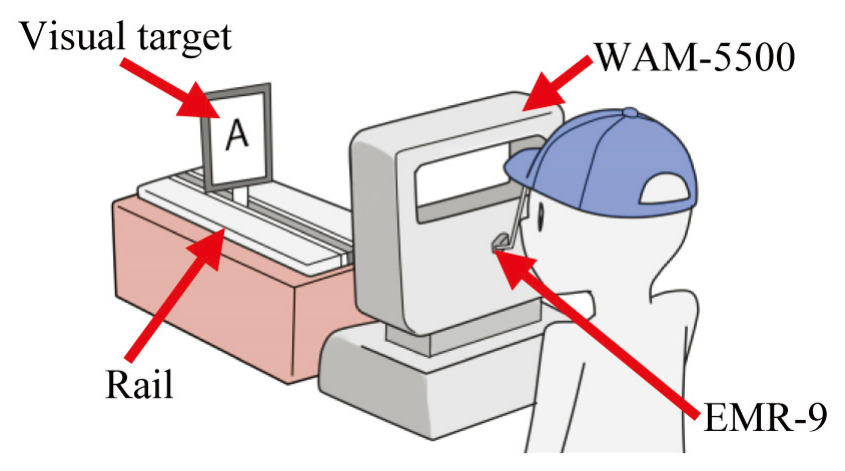

図 3 実験装置の構成

表 1 使用した媒体の解像度と輝度, 照度

\begin{tabular}{|c|c|c|c|c|}
\hline & $\begin{array}{l}\text { 照度 } \\
\text { (lux) }\end{array}$ & $\begin{array}{c}\text { 輝度 }\left(\mathrm{cd} / \mathrm{m}^{2}\right) \\
\text { (白ピーク／黒背景) }\end{array}$ & コントラスト & $\begin{array}{r}\text { 解像度 } \\
\text { (ppi) }\end{array}$ \\
\hline Paper & 380 & $(105 / 6.6)$ & 15.4 & \\
\hline $\mathrm{KOBO}$ mini & 380 & $(67 / 9.2)$ & 7.2 & 200 \\
\hline iPod & & $120 / 4.3$ & 34.9 & 326 \\
\hline PS Vita & & $107 / 6.0$ & 31.4 & 221 \\
\hline
\end{tabular}

ことを考慮して，奥行き方向に移動中もグレアが生じない ように配置した。

文字フォントについては，これまで明朝体とゴシック体に ついて予供実験を行い, 左右対称の文字「東」を用いて, 輻輳 角の変化量には一定の傾向は見られなかったものの, 調節の 変化量についてはフォント依存性について示唆する結果を 得ている8). すなわち 42 ポイント (13mm, 視角 1.241 度) のフォントでは明朝体, 21 ポイント $(6.5 \mathrm{~mm}$, 視角 0.620 度) の小さいフォントではゴシック体の方が調節の変化量 が大きい傾向があることを示している．このことはフォン 卜を構成する線幅が調節の変化量に影響を与える可能性が あることを示唆する. 一方, 実験後に小さい方のフォント が見にくかったという内省報告を受けており，フォントの 効果を確かめるには充分に大きなフォントにする必要があ ると考えた。そこで被験者の視力差による影響を受けない 充分な大きさのあるフォントを用いて，かつ左右対称の文 字「A」を各媒体に表示し提示視標とした (図 4). 文字サイ ズには, 高さ $15 \mathrm{~mm}$ （視角 1.432 度）と $10 \mathrm{~mm}$ （視角 0.954 度）の 2 種類を用意した．実際の見えの大きさを統一する ため, 文字の高さを実測した単位 $(\mathrm{mm})$ を新たな基準とし た。さらに明朝体とゴシック体に似ており，より沉用性の ある欧文文字フォント Arial と Times New Roman の 2 種 類を選択し，これらを組合せた合計 16 パターンを被験者 に提示し，実験を行った。なお KOBO mini については, Times New Roman のフォントがシステムに準備されて おらず，自動的に細字のフォントに変換されたので，この フォントを用い, 以下の解析では $\mathrm{KOBO}$ mini についても Times New Roman として記述した。

被験者は本学の男子大学生 7 名（20２1 歳）である. い ずれの被験者も提示した視標が $60 \mathrm{~cm} \sim 40 \mathrm{~cm}$ の移動範囲内 ではっきり見えることを事前に確認した。しかし，今回の 実験条件において, 調節が必ずしも変化しない被験者がい

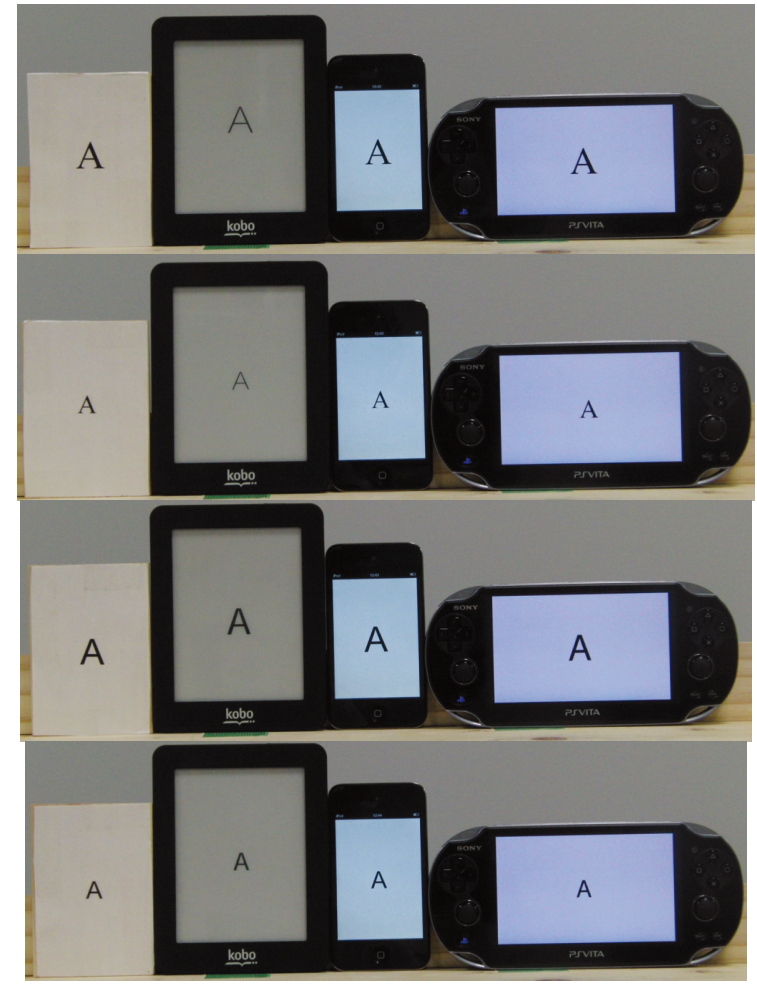

図 4 各提示媒体に表示した視標（上から Times New Roman:15mm, Times New Roman:10mm, Arial:15mm, Arial:10mm)

たため, 良好に調節が変化した 5 名の結果を解析に用いた. そのうち被験者 $\mathrm{A}$ は視力 $1.5, \mathrm{~B}$ は $0.9, \mathrm{C}$ は $1.5, \mathrm{D}$ は 1.0，E は 1.0 であった。これらの視力は，いわゆる $5 \mathrm{~m}$ 視 力であり $5 \mathrm{~m}$ 離れたランドルト環の切れ目がわかる能力で ある. 被験者が正常な視力を有することを示す指標である が，本実験で対象とした $60 \mathrm{~cm} \sim 40 \mathrm{~cm}$ の視力を保証するも のではない。そこで，予備実験を参考にして大きめのフォ ントを用い，さらにあらかじめ各被験者にはっきり見える か事前に確認することにより, 視力差の影響をできる限り 排除した。

本実験は，東海大学「人を対象とする研究」に関する倫 理委員会規定にしたがい実施した。

\section{5. 実 験 結 果}

調節応答は，目標点に達しても，しばらく動き続ける性 質がある ${ }^{11)}$.WAM-5500 の測定間隔が約 $7 \mathrm{~Hz}$ であること から, 調節測定值は測定值とその前後 3 要素の計 7 サンプ ル 1 秒単位で移動平均をとった。同様に, 輻輳眼球運動の 測定間隔が $60 \mathrm{~Hz}$ であることから, 輻輳は測定值と前 29 要 素, 後 30 要素の計 60 サンプル 1 秒単位で移動平均をとっ た。測定結果の典型例を，フォント Arial, $15 \mathrm{~mm}$ で視標を KOBO mini に表示した場合における被験者 $\mathrm{A}$ の結果を例 に取り図 5, 6 に示す。

\section{1 実験結果・調節}

図 5 は調節の測定結果になっており, 縦軸が diopter (D) 值，横軸が時間となっている。レールの駆動・停止タイミ 


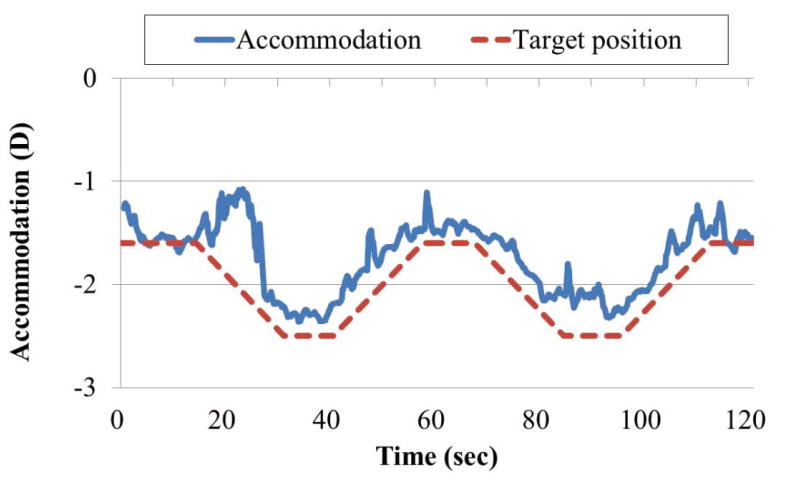

図 5 調節と視標位置 (被験者 $\mathrm{A}, \mathrm{KOBO}$ mini:Arial:15mm)

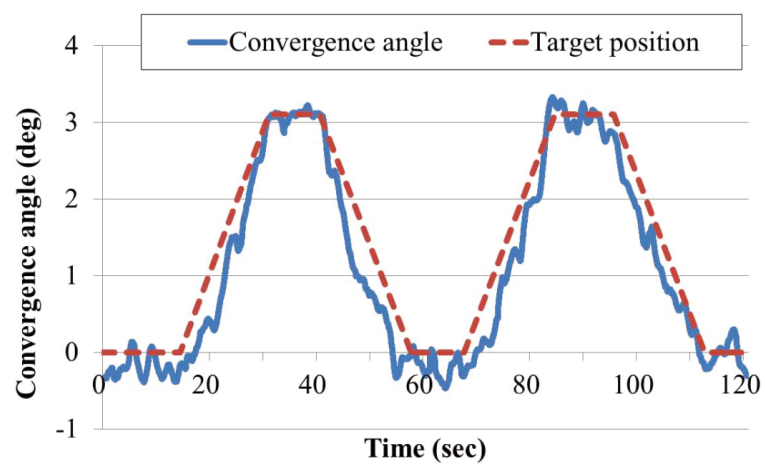

図 6 輻輳と視標位置 (被験者 $\mathrm{A}, \mathrm{KOBO}$ mini:Arial:15mm)

ングから視標の位置を算出し, diopter 換算して目安として グラフに示している. 図 5 の調節反応の結果を見てみると, 多少の誤差はあるものの, 視標の動きに追従して反応して いることがわかる．視標が $40 \mathrm{~cm}$ (-2.5D) の位置にある時, 調節が視標の位置よりもやや遠方に合わせられている. 調 節は対象に正確に焦点を合わせる反応ではなく，ある程度ず れがあり, 個人差も存在することが分かっている ${ }^{12)}$. 宮尾 らは充分な照度あるときには, 調節は対象物よりも約 $0.4 \mathrm{D}$ 遠方に合わせているということを報告している(10)13) 15).

\section{2 実験結果 ·輻輳}

図 6 は図 5 と同時に測定した同被験者の輻輳の測定結果 になっており，縦軸がオフセットした位置からどれだけ輻 輳角が変化したかの值 $(\mathrm{deg})$, 横軸が時間（sec）となって いる. 測定值は，オフセットした視距離 $60 \mathrm{~cm}$ の位置で值 が 0 となり, それよりも奥に視線を合わせると負の值を取 り，手前に視線を合わせると正の值を取る.図 6 を見ると， 輻輳の変化量は視標の移動に対してかなり忠実に応答して いることがわかる.

\section{6. 解 析}

測定結果から，視標の動作前後で測定值の変化量に注目 した. 調節測定值の変化が， 2 秒間で $\pm 0.3 \mathrm{D}$ 以内の箇所を 調節安定位とし, 最初の視標移動後の静止している時, 計 4 カ所の調節安定位の測定值を取得した。輻輳は, タイム レコードを確認し，調節安定位と同じ個所で測定值を取得
した．取得した值をグラフ上にプロットし，手前から奥へ の変化量を線で結んだものを図 7,8 に各被験者ごとに比 較要素別で示す。図中で空白になっている部分は, ノイズ やエラーで久損したデータの部分である.

\section{1 解析 · 調節}

図 7 において, 縦軸が調節の変化量（D), 横軸が表示媒 体，フォントサイズといった比較要素を示している．直線が Arial, 破線が Times New Roman を表している。視標の 60〜 40cm の動きを diopter に換算すると $-1.67 〜-2.5 \mathrm{D}$ であり，その位置をグラフ上に基準として横棒線で示して いる。また，その差は $0.83 \mathrm{D}$ である。調節微動を考慮し， $0.83 \pm 0.2 \mathrm{D}$ の範囲を「基準值に近い值」として，調節変 化量の結果を被験者別に考察する.

被験者 $\mathrm{A}$ では，KOBO mini の調節変化量が「基準值 に近い值」を示している。調節が視標の位置に正確に合 わせられていた場合, 理論上その変化量も $0.83 \mathrm{D}$ に近づ くはずである，KOBO mini の調節変化量（線の長さ）は $0.83 \pm 0.2 \mathrm{D}$ と，「基準值に近い值」と充分に言えるだろう。 KOBO mini:Times New Roman:10mm（2 回目）のフォ ントの結果のみ他の $\mathrm{KOBO}$ mini の結果と違い, 遠方への ずれが見られるが変化量はほぼ同じである。被験者 B で は, KOBO mini:Arial:10mm と iPod:Arial:15mm の調節 変化量が「基準值に近い值」を示している。これらの結果 では, Arial より Times New Romanの方が調節変化量は 小さい. 被験者 C では, iPod:Arial:10mm と PS Vita : Times New Roman:10mm を除き, フォントサイズ $10 \mathrm{~mm}$ の調節変化量が基準值より小さい傾向が見られる，KOBO mini:Times New Roman:15mm と iPod:Arial:15mm (2 回目）を除き， $15 \mathrm{~mm}$ フォントの調節変化量が「基準值 に近い值」となっている。被験者 D では，データ久損が 多く全体的な比較はできないが, Paper:Times New Roman:15mm と KOBO mini:Times New Roman:15mm, 10mm, PS Vita:Arial:10mm の調節変化量が基準值に近 い. 最後に被験者 E では, Paper:Arial:10mm（1 回目） と KOBO mini:Arial:10mm, PS Vita:Times New Roman:10mm（1 回目）の調節変化量が基準值に近い。これ らの結果から, KOBO mini の $10 \mathrm{~mm}$ のフォントが被験者 全般に渡って調節変化量は基準值に近いこと，他の媒体も 含めて $10 \mathrm{~mm}$ フォントの調節変化量が基準值に近いという 傾向が示された。

\section{2 解析 · 輻輳}

図 8 において, 縦軸は輻輳角変化量 $(\mathrm{deg})$, 横軸は比較要素 となっている．線の違いはフォントの種類を表している．才 フセットを行った遠方視 $(60 \mathrm{~cm})$ の地点を示す $0 \mathrm{deg}$ と, 近 方視 $(40 \mathrm{~cm})$ の地点を示す $3.1 \mathrm{deg}$ の位置をグラフ上に横棒 線で示している．全体的に，輻輳角変化量は視線の動きに忠 実である，被験者別に見ると，被験者 A では, PS Vitaの結 果において輻輳角の測定值は視標位置よりも $1 \mathrm{deg}$ 程度近方 に動いているが，その他では比較要素による違いは見られな 

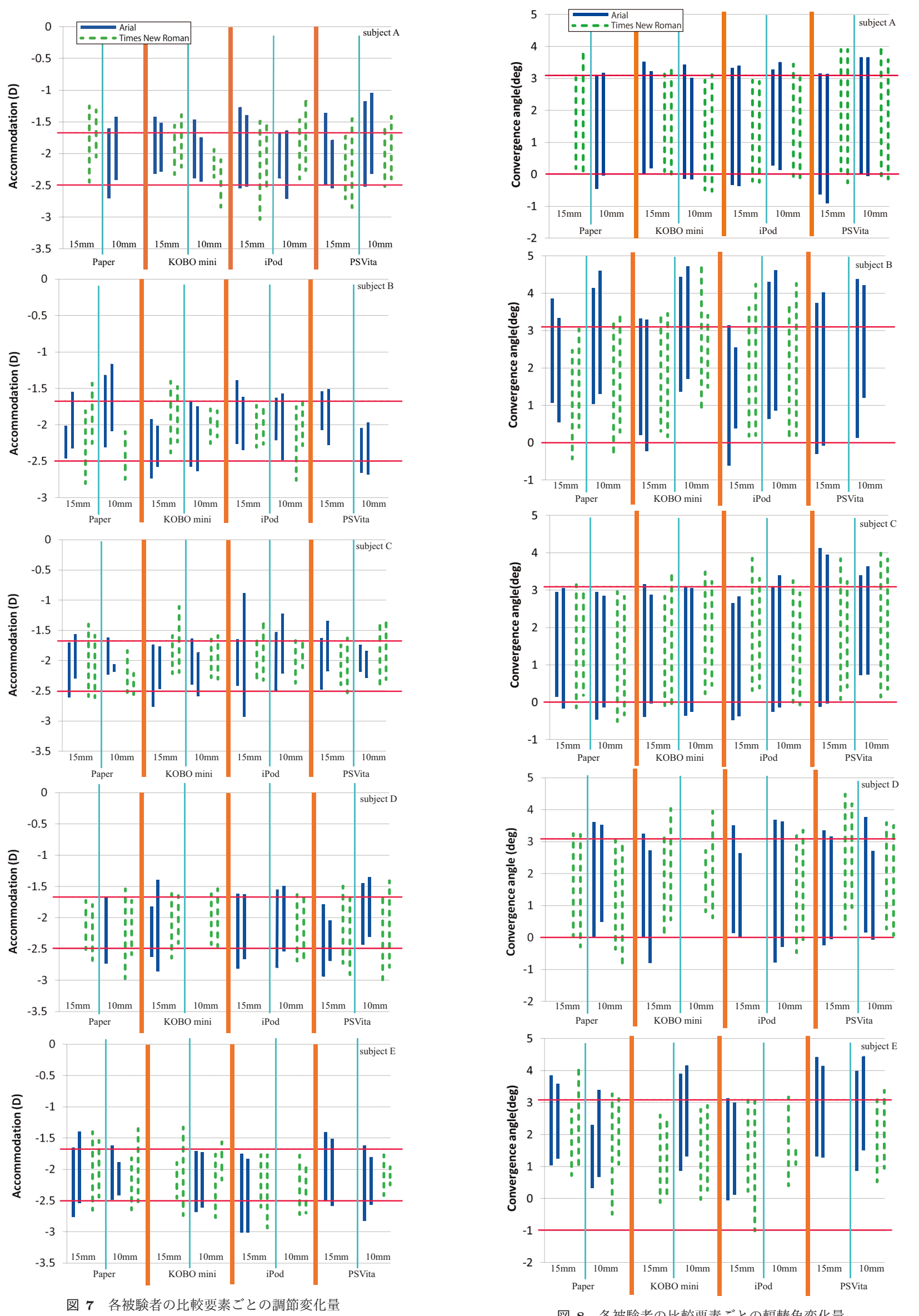

図 8 各被験者の比較要素ごとの輻輳角変化量 
い. 被験者 Bでは, 測定值が視標位置より近方に輻輳角が変 化する結果が多く見られた。被験者 Cでは，ほぼすべての結 果で輻輳角の測定值は視標位置に正確に対応しているが, PS Vita での輻輳角の測定値は $1 \mathrm{deg}$ 程度近方に動いている. 被験者 D では, KOBO mini:Times New Roman:15mm (2 回目) と KOBO mini:Times New Roman:10mm（2 回 目), PS Vita:Times New Roman:15mm(1 回目, 2 回目) では, 近方視時の測定值が視標位置よりも近方になってい るが，それ以外では，近方視時の測定值は視標位置に正確

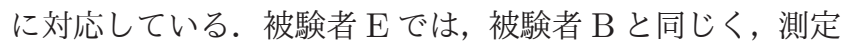
值が視標位置より近方に輻輳角が变化する結果が多く見ら れた.

被験者 B，E は他の被験者に比べ，ほとんどの条件で輻 輳が近方に動く傾向があるが，近方にスライドしているだ けで輻輳変化量は視標変化量とほぼ同じである.しかし他 の被験者はPS Vita を除き, ほぼ正確に追従しており, 被 験者 B では校正時のオフセットがずれたか，もしくは被験 者 B のみの輻輳眼球運動の固有の傾向と考えられる. 被験 者 Eにおいても, KOBO mini:Times New Roman と PS Vita で視標位置より近方になっている傾向が見られている が，その值は $1 \mathrm{deg}$ 程度であり, 他の被験者の PS Vita の 傾向と同様である. 総じて輻輳変化は視標変化に正確に対 応しているが, 被験者全員に PS Vita の輻輳が $1 \mathrm{deg}$ 程度 近方に動いている傾向がある.

\section{7. 考 察}

各被験者の個々の傾向については分析したが全体的な傾 向がつかめないため, 調節変化量と輻輳角変化量について エラー值を除く, 図 7,8 の被験者 5 名すべてのデータを, 媒体，フォント，フォントサイズごとに平均した。 その結果 を図 9, 10 に示す。それぞれ，理論上の変化量である 0.83 D と $3.1 \mathrm{deg}$ の值を横棒線で示している.

まず, 調節変化量について考察する。紙と PS Vita で は,Arial より Times New Roman の調節変化量の方が大 きい. KOBO mini と iPod では傾向が逆である. KOBO mini:Times New Roman:10mm の調節変化量は特に小さ い.しかし,いずれの媒体, フォント,フォントの大きさの 結果を見ても, 理論上の変化量である $0.83 \mathrm{D}$ に対して,その 誤差は $0.2 \mathrm{D}$ 程度と言われている調節微動 ${ }^{16)}$ のほぼ範囲内 である.

輻輳変化量については，すべての条件で輻輳変化量が理 論值とほぼ同じ結果となった（図 10)。しかし, PS Vitaの $15 \mathrm{~mm}$ のフォントサイズと iPod の Arial: $10 \mathrm{~mm}$ の輻輳変 化量が最大で $1 \mathrm{deg}$ 程度大きい傾向が見られた。 $1 \mathrm{deg} の$

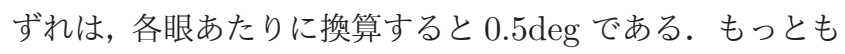
視力の高い中心窩の大きさが約 $1 \mathrm{deg}$ であることを考慮す ると, 被験者は中心窩で文字を捉えていたと考えることが できる.

今回の実験では媒体に文字を表示して奥行き方向に移動
させて，それを注視させている．調節は文字にピントを合 わせ続ける必要があり, 輻輳眼球運動は両眼の中心窝に文 字を保持し続ける必要がある。そのため，それぞれ単体で 奥行き方向の移動に追従する必要があるが，調節と輻輳眼 球運動は連携しておりお互いに影響し合っている，この働 きは輻輳性調節あるいは調節性輻輳と呼ばれている ${ }^{17)}$ ，実 際に今回の実験結果を見ても，媒体間，フォント間，フォ ントの大きさ間の調節変化量と輻輳変化量の結果は整合し ている. 眼球運動により中心窩付近に文字を保持し, 調節 によりその文字にピントを合わせる必要がある，もっとも 視力の高い中心窩の大きさが 1 度程度であることを考える と, 後者の方の要求精度が高いのではと推察される. その ような視点から図 9 の調節変化量の結果を眺めると, 媒体, フォントの種類, フォントの大きさによって調節変化量に 違いがある。このことは，それぞれについて文字を読むと きに必要な調節の精度が異なることを意味し, 文字の読み やすさを評価するパラメータになることを示唆している.

\section{8. むすび}

小型タブレットや電子書籍の普及により紙だけのときに 比べ利用スタイルが多様化している．移動体内での利用も 日常化し，これら媒体の見やすさを目のピント調節と輻輳 の追従精度から評価できないか検討した。そこで，小型タ ブレットや電子書籍を奥行き方向にリニアに移動させるこ とができる装置と組合せ, 眼球の水晶体調節と輻輳眼球運動 を同時に測定する実験装置を開発し，実験を行った。調節・ 輻輳の変化量を求めた結果, 調節変化量は理論上の $0.83 \mathrm{D}$ という変化量に対して $\pm 0.2 \mathrm{D}$ 程度の調節微動の範囲内の值 を示した。しかし，その変化量は，媒体，フォントの種類， フォントの大きさによって違いがあることが示され，文字 の読みやすさなどを評価するパラメータになることが示唆 された。

輻輳変化量は, 視標の奥行方向の動きに対してかなり正確 に追従する傾向を示し, フォントの種類, フォントの大きさ による一定の傾向は見られなかった。媒体の種類では, PS Vita において 1 度程度近方に動いている傾向が見られた。

今回用いた機器は, 単体では輝度, コントラストをある 程度調整することは可能であるが，主にゲーム機として開 発されたPS Vitaでは色温度を含めて厳密に揃えることは 困難であった。 今後は, カラーフィルタ, ND フィルタを併 用し，正確に主観的な明るさ，コントラストを揄えて，フォ ントやフォントの大きさ, 色, コントラスト比等を変化さ せて, 組織的に調べる必要があると考えている。また，こ の研究を通して, 媒体ごとの見やすい, 読みやすい表示法 を提案して行きたいと考えている.

\section{〔文献〕}

1）荒瀬: “編集デザイン入門”, 出版メディアパル (2007)

2) 中野 et al.: “ぼやけによる視力低下に強いユニバーサルデザインフォン 卜開発 (1) 〜明朝体, ゴシック体，ユニバーサルデザイン書体の 

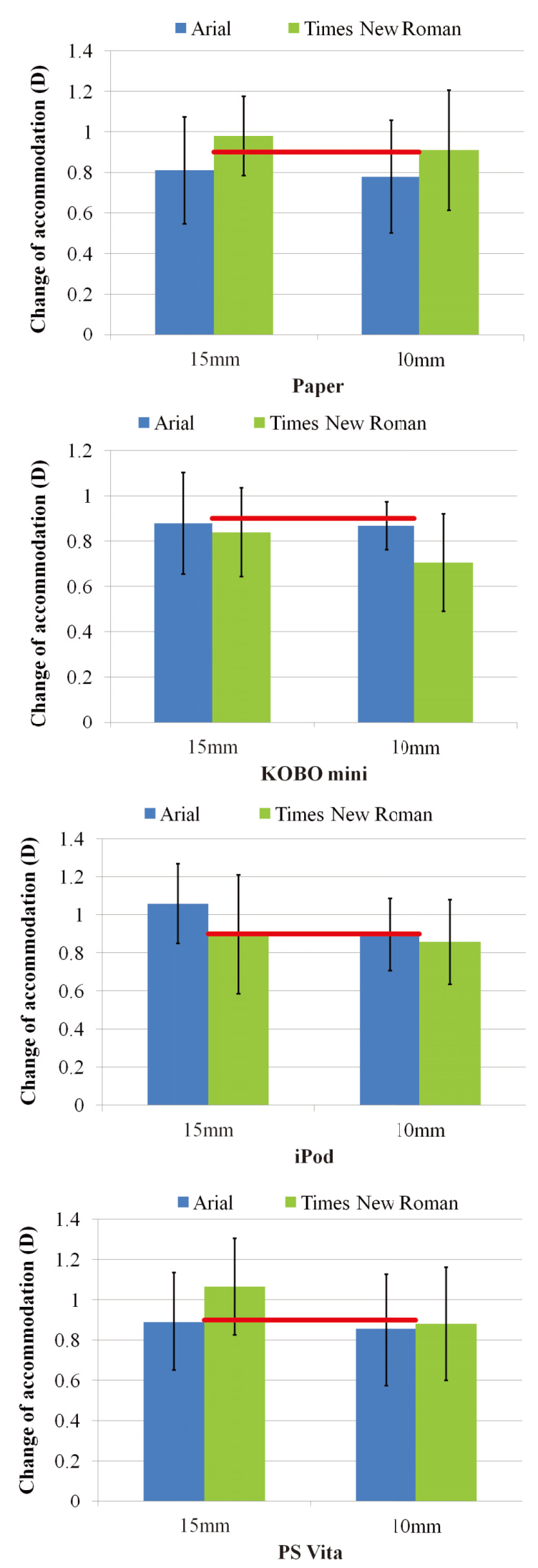

図 9 調節変化量の平均
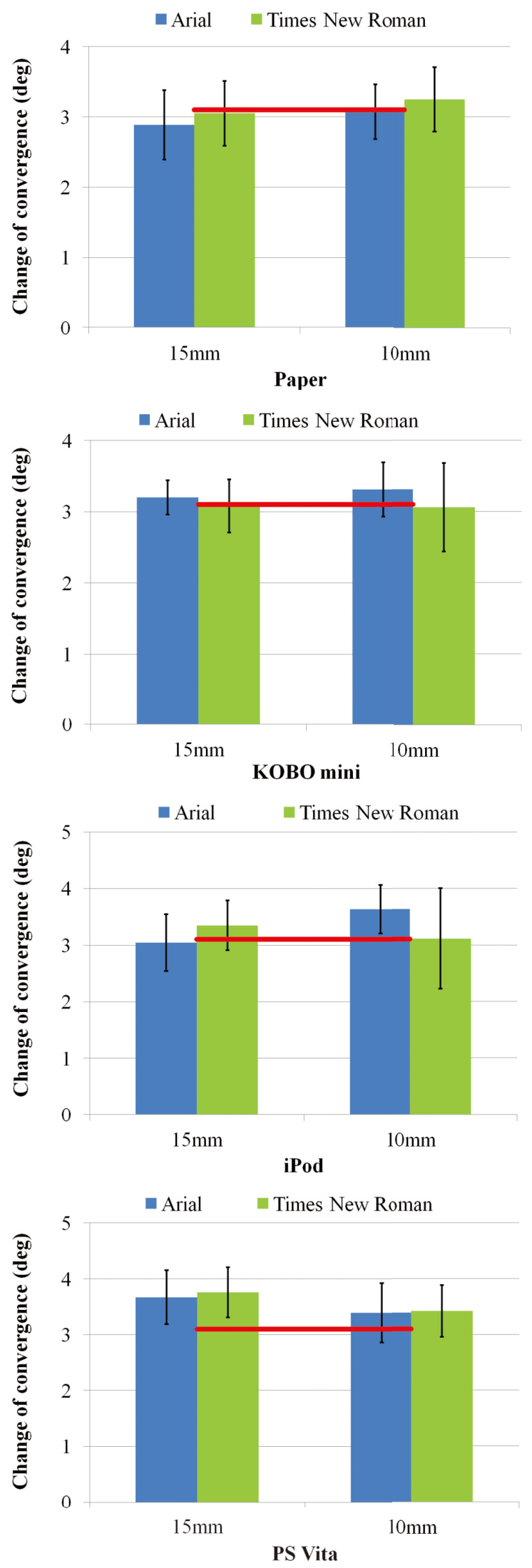

図 10 輻輳変化量の平均 
可読性”, http://hakuhodo-diversitydesign.com/hdd/wp-content/ uploads/2013/12/font-C_j·pdf, 2015, 7, 27 参照

3）中野: “モリサワフォント（UD 書体）の可視性・可読性に関する比較 研究報告", https://www.morisawa.co.jp/font/about/knowledge/ud/ pdf/UDFontResearchReport.pdf, 2015, 7, 27 参照

4）窪田, 松戸, 丸本: “高齢者の視覚特性に適合した液晶ディスプレイの文字 表示条件〜表示輝度, コントラスト, 文字サイズの主観的な適正值の若齢 者との比較〜”，映像情報メディア学会誌, 53, 9, pp.1335-1342(1999)

5）窪田，松戸：“加齢による視覚特性の変化がディスプレイからの文字 情報の読み取り速度に及ぼす影響”，映像情報メディア学会誌，55，4， pp.583-587(2001)

6) Yuzo .H et al.: "Effect of font types and pixel density of electronic displays on the legibility of Japanese characters", Proceedings of IDW' 14, VHF4-2, pp.992-995, (2014)

7）清原 et al.: “文章の表示メディアと表示形式が文章理解に与える影響”, 日本教育工学雑誌, 27, 2, pp.117-126(2003)

8）横山, 菊池, 高比良, 山田: “奥行き方向に移動する視対象に対する輻輳 と調節変化の分析”, 信学技報, 113, 468, pp.271-276 (2014)

9) Amy L., Sheppard and Leon N., Davies: "Clinical evaluation of the Grand Seiko Auto Ref/Keratometer WAM5500", Opthal.Physiol.Opt. 30, pp.143-151 (2010)

10）塩見 et al.: “実物体と $2 \mathrm{D}$ 映像, $3 \mathrm{D}$ 映像を用いた水晶体調節反応と輻 輳運動の長時間同時測定-若年者と中高齢者の立体視機構の違い_”日本 バーチャルリアリティ学会論文誌, 16, 2, pp.139-148(2011)

11）山田,鵜飼, 石川：“調節ステップ応答の指数関数近似による解析”, 日 本眼光学学会誌, 9, pp.123-126(1988)

12）泉: “3 次元映像の基礎”, オーム社 (1995)

13）長谷川, 宮尾 et al. : “ヘッドマウントディスプレイ上の立体映像への水 晶体調節反応”, シンポジウム「モバイル'10」, pp.121-124 (2010)

14）大森, 宮尾 et al.: “立体映像に対する水晶体調節の測定”, 日本視覚学 会 2004 年夏季, VISION, 16, 4, pp.223-226 (2004)

15）藤掛，宮尾 et al.: “立体映像認知時における水晶体調節の評価”, 電 子情報通信学会技術研究報告, HIP，ヒューマン情報処理，105，165， pp39-42 (2005)

16) Charman,WN. and Heron,G. : "Fluctuations in accommodation : a review.", Ophthal. Physiol.Opt. 8:153-164(1988)

17）艼阪, 中溝, 古賀: “眼球運動の実験心理学”, p253, 名古屋大学出版会 (1993)

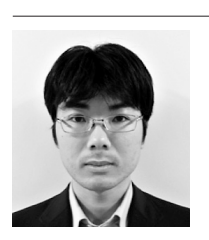

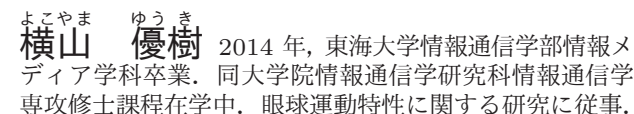

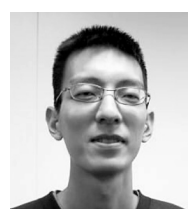

势比良英朗 2014 年, 東海大学情報通信学部情報 メディア学科卒業. 同大学院情報通信学研究科情報通信 学専攻修士課程在学中. 電子書籍に関する研究に従事.

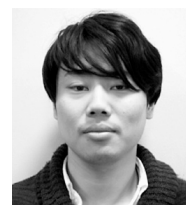

仝ちづき信哉 2015 年, 東海大学情報通信学部情報义 ディア学科卒業. 同大学院情報通信学研究科情報通信学 専攻修士課程在学中. 眼球運動特性に関する研究に従事.

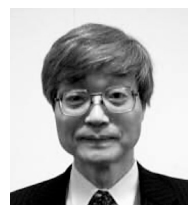

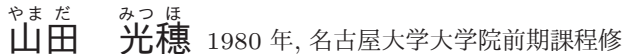
了. 同年, NHK に入局. 現在, 東海大学情報通信学部情 報メディア学科教授. 工学博士. 視覚系の情報処理およ び眼球運動の制御機構, ヒューマンインタフェースの研 究に従事．正会員。 